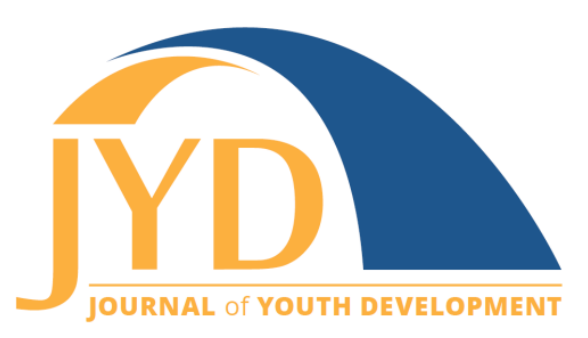

http://jyd. pitt. edu/ | Vol. 14 Issue 2 DOI 10.5195/jyd.2019.830 | ISSN 2325-4017 (online)

\title{
Special Issue: Perspectives on Immigrant, Refugee, and Border Youth
}

\author{
Corliss Outley \\ Texas A\&M University, Department of Recreation, Park and Tourism Sciences \\ coutley@tamu.edu
}

Jennifer A. Skuza

University of Minnesota, Extension Center for Youth Development

skuza@umn.edu

\begin{abstract}
The positive development of immigrant, refugee, and border youth is a significant issue among youth development researchers, practitioners, and policy makers. As evidenced by the papers in this issue, the field has made great strides in research and programmatic approaches and has begun to identify specific developmental pathways. This special issue is intended to ignite a spark in future research and programming, encouraging the field of youth development to further develop interdisciplinary perspectives that include not only a focus on immigrant, refugee, and border youth, but also include their voices.
\end{abstract}

Key words: immigrant, refugee, and border youth; youth development

\section{Purpose of This Special Issue}

The purpose of this special issue is to advance the field of youth development with a collection of studies that explores the lives of immigrant, refugee, and border youth in varying developmental contexts and its implications for practice. This special issue also provides space for youth to negotiate, resist, and respond to their sociopolitical marginalization by using their voices, telling their stories, and writing about their experiences, which can create broader understanding of the youth in the very communities impacted by our work. After all, youth are the authors and experts on their lives. By including youth submissions for this special issue we

(cc) EY New articles in this journal are licensed under a Creative Commons Attribution 4.0 License. This journal is published by the University Library System, University of Pittsburgh and is cosponsored by the University of Pittsburgh Press. The Journal of Youth Development is the official peer-reviewed publication of the National Association of Extension 4-H Agents and the National AfterSchool Association. 
Perspectives: Immigrant, Refugee, and Border Youth

hope to expand the dialogue on immigrant, refugee, and border youth in the United States by bringing multiple voices and perspectives of researchers, practitioners, and youth to the forefront. We are grateful to the youth development practitioners who encouraged young people to participate in this important opportunity.

\section{Key Terms}

An immigrant is a non-native person who chooses permanent residence in a foreign country and has obtained the legal right to seek citizenship and employment. In contrast, a refugee is an individual who has been forced to flee his or her home country because of threat of war or persecution based on a well-founded fear of being persecuted for reasons of race, religion, nationality, membership of a particular social group, or political opinion (U.S. House of Representatives, n.d.). Other designations based on federal policy within the United States include undocumented immigrants (residents within the United States that have not sought legal status for residency), asylees (people who meet the definition of a refugee and currently reside in the United States but have decided to not return to their home country), and other individuals who have been displaced forcibly due to political population transfers, natural disaster, or deportation. Border youth, in the context of this special edition, refers to young people who live on either side of the México-United States border.

\section{Population Changes}

The racial and ethnic diversity of the U.S. population has grown dramatically over the past decades and is expected to change further in the future. These changes have implications for our nation, particularly if racial and ethnic disparities in education, health, employment, wealth, and other socioeconomic indicators continue to widen. In order to move forward we have to understand the demographic changes and how the data can assist us in ensuring the success of all youth, especially among immigrant, refugee, and border youth. Today, immigration is one of the top issues being discussed in the United States due to steady increases in the number of immigrant, refugee, and border youth entering and settling in the United States. These demographic changes are significant and have resulted in the introduction of a variety of cultural, racial, ethnic, linguistic, and religious changes and practices to U.S. citizenry. However, despite a rich U.S. history of welcoming immigrant newcomers through Ellis Island, the current immigrant, refugee, and border youth populations have frequently faced unique challenges related to cultural and social adaptation, language proficiency, poverty, and discrimination. 
Perspectives: Immigrant, Refugee, and Border Youth

Furthermore, the national sociopolitical level rhetoric has led to the marginalization of these youth voices in research, mainstream media, health, juvenile justice, education, and policymaking spheres.

\section{Why This Special Edition is Important}

Currently nearly one third of the U.S. overall population-over 84.3 million people-is made up of immigrants and their U.S.-born children (Zong \& Batalova, 2017). Ten countries, Mexico (27\%), India (6\%), China (5\%), Philippines (5\%), El Salvador (3\%), Vietnam (3\%), Cuba (3\%), Dominican Republic (2\%), Korea (2\%), and Guatemala (2\%), total over $60 \%$ of the U.S. immigrant population. In 2017, among all people who had been born in the United States and had at least one immigrant parent, $44 \%$ were children between the ages of 0 and 17, compared to $23 \%$ in that age range among all people born in the United States to parents who were also born in the United States (Radford, 2019). Close to six million $(5,760,000)$ of the youngest children (0-5 years of age) and over 12 million $(12,106,000)$ of youth $6-17$ years of age had at least one immigrant parent (Migration Policy Institute, n.d.). Second-generation children, born in the United States to at least one foreign-born parent, accounted for 88 percent (15.9 million) of all children under age 18 with immigrant parents. The remaining 12 percent (2.1 million) were born outside the United States.

In 2016, the top five U.S. states with the largest total number of children under age 18 living with immigrant parents were California (4.3 million), Texas (2.4 million), New York (1.5 million), Florida (1.3 million), and Illinois $(767,000)$ (Zong \& Batalova, 2017). These five states accounted for 57 percent of all children with immigrant parents residing in the United States. Approximately 5.1 million children under age 18 lived with an unauthorized immigrant parent during the 2009-13 period, representing seven percent of the U.S. child population. About $79 \%$ (4.1 million) of these children were U.S. citizens, another $19 \%(959,000)$ were themselves unauthorized, and two percent $(113,000)$ were legally present.

According to the Child Migration Data Portal (2019), immigrant and refugee youth are the fastest growing group of children in the United States and by 2050 are expected to make up one third of all U.S. children (Zong \& Batalova, 2017). Immigrants and their children are projected to account for the great majority (88\%) of U.S. population growth through 2065 (Radford, 2019). Research suggests these young people often face many challenges as they adapt to U.S. culture and strive to succeed in a new environment. Their journeys follow complex paths and variations exist in their life courses, the reasons for migration, the levels of 
Perspectives: Immigrant, Refugee, and Border Youth

difficulty they experience, and the eventual outcomes. While some youth thrive in their cultural adaptation, others struggle to find their balance. For example, census data shows that immigrants in the United States have lower levels of education overall in comparison people born here (Radford, 2019). However, this varies based on the differing populations and is illustrated in the career trajectories of immigrants from varying geographic locations. Documented immigrants are most likely to pursue professional, management, or business and finance jobs (37\%) or service jobs (22\%), while undocumented immigrants that work in the service industry (32\%) or construction occupations (16\%) are more common (Radford, 2019). This is further reflected in the poverty levels among immigrants being much higher than among the general U.S. population. Currently, more than a quarter (26\%) of children of immigrant families live below the poverty level, compared with $19 \%$ of children whose parents were native born.

Turning to border youth-particularly child migrants from Latin American countries on the México-U.S. border-they are at risk of abuse, trafficking, and exploitation, especially if they travel alone and through irregular migration pathways. This includes the dangers youth meet en route to the United States and the youth who live surreptitiously in the United States. Youth on either side of the border are often persecuted by Mexican and U.S. border security forces or targeted for removal from the United States (Bejarano, 2015).

The circumstances surrounding immigrant, refugee, and border youth uniquely influence their life experiences. Supports, opportunities and connections are needed to help youth navigate everyday life and the challenges they encounter. Youth programs can be important resources in their lives. For example, the environments found in youth programs are more relaxed than formal educational settings and can provide the space for youth to take break, sort things out, build camaraderie, or discover an interest (Skuza, 2005). These environments also serve as developmental contexts and can be places where they can flourish over time. These programs are also important settings for immigrant, refugee, and border youth to develop their selfconfidence; express and negotiate their personal, racial and ethnic identities; and adjust to their new life within the United States. Given immigrant, refugee, and border youths' experience with the questions of belonging, ethnic identification, and cultural adaptation, the field of youth development sets the stage for their development and overall well-being (Mata-Codesal, Peperkamp, \& Tiesler, 2015). 


\section{Issue Overview}

It is essential that we deepen our understanding of the life experiences of the burgeoning immigrant, refugee, and border youth populations and the role that youth work practice plays in their lives. The isolation, discrimination, separation of families and fear of deportation that many of these youth face has led to trauma that must be addressed. As the number of immigrant, refugee, and border youth continues to rise within the United States and around the world, there need to be opportunities for scholars, practitioners, educators and policy makers to learn from each other. In addition, given the sociopolitical environment today, youth development workers have ethical and moral responsibility to protect all children and youth, regardless of status, as they journey on the pathway toward adulthood. Collectively, this issue's special collection generates several common themes in order to create a space to hear the voices of scholars, practitioners, and youth.

First, there is still little understanding of the developmental experiences of these youth within the U.S. out-of-school time landscape. In this issue Gabriel (2019) discussed the role of religion in the context of mental health among Filipino emerging adults. She introduces the reader to the history of the group and its cultural understanding of Kapwa that directs their lives. Additionally, Tzenis (2019), contextualizes the gap between the cultural and professional aspirations of Somali American youth and their educational achievement in Minnesota. Detailing the importance of aspiration in positive youth development, she investigates the influence of both their cultural identities and Western social engagement on those aspirations. This issue also includes Manzano-Sanchez, Matarrita-Cascante and Outley (2019) detailing the barriers facing Latinx youth in their aspirations for higher education. Furthermore, they discuss the various types of support they receive regarding those aspirations. Examining the resiliency of adolescent refugees, Stark, Quinn, Hennessey, Rutledge, Hunter and Gordillo (2019) set out to understand the strengths and resources supporting these youth in northeast Texas.

Second, the challenge of providing support, opportunities, programs, and services continues to be an area of shared concern. In this issue, Verde, Watkins, Enriquez, Nater-Vazquez and Harris (2019) detail the positive effects of cultural and trauma-informed service-learning in youth development practices and programs. Specifically, they discuss these practices within the context of their assistance of Puerto Rican youth displaced by Hurricane Maria. Likewise, Wu, Outley, and Matarrita-Cascante (2019) discuss the influence of cultural immersion camps on Asian American youth's ethnic identity. In further detail, they recommend such opportunities to provide Asian American emerging adults with culturally safe and supportive networks. In this 
Perspectives: Immigrant, Refugee, and Border Youth

assessment, Skuza (2019) evaluates a program focused in serving teens within the Somali diaspora. In doing so, she provides both limitations and recommendations to further the success of youth within such programs. Also featured are the empirical findings of a study by Moncloa, Erbstein, Subramanium and Carrasco (2019) of Latinx-serving youth development programs in rural, suburban and urban communities in California.

Third, though the immigrant, refugee, and border youth in the United States have faced extraordinary situations, their experiences are also deeply shaped by circumstances and histories unique to their countries of origin and the reception and policy contexts in which they migrate. León (2019) discusses the role new federal immigration policies have had on the juvenile justice system and its practices currently facing youth on the border. Also featured in this issue, Rodriguez, Rodriguez, and Zehyoue (2019) detail the findings of a content analysis regarding the ways in which DACA youth utilize social media. In another study, Langley, Powell, Liechty, Haller, and Anderson (2019) further extend upon the experiences of DACA-status youth in looking into their leisure activities and social support systems.

Fourth, while the youth development field espouses the importance of youth voice, the inclusion of these voices within our scholarship-particularly research designs and publications-has been virtually absent. Despite this dominating narrative, Journal of Youth Development believes in serving as the bridge between scholars and practitioners as illustrated in the inclusion of youth essays in this special issue. The essays by Zahra Ali, Andres Guerra, Noor Hassan, Julia Joo, Titus Kariuki, Dirdra Medina, Brittany Mendez, Miski Mohamed, J. B. and D. X. Rodriguez, and Hwanhui Seo provide a first glimpse into the possibilities within scholarship where youth are not used just as a study population, but have a true authentic voice in research and programming. We are grateful to the young authors who made contributions to this special issue. We also want to thank the guest co-editors Aishia Brown (University of Louisville), M. Gayle Gabriel (Texas A\&M University) and Jill Martz (Texas A\&M University). Their contributions added to the richness of this special edition and the spirit of collaboration that built it.

\section{Conclusion}

In conclusion, the diversity of topics, methodological designs, programs, and youth voices covered in this special issue demonstrates significant progress in understanding challenges and promises of immigrant, refugee, and border youth. As evidenced by the papers in this issue, the field has made great strides in research and programmatic approaches and has begun to identify specific developmental pathways (e.g., social inclusion, health, language proficiency, 
Perspectives: Immigrant, Refugee, and Border Youth

racial/ethnic identity). The positive development of youth, especially immigrant, refugee, and border youth, remains a significant issue among youth development researchers, practitioners, and policy makers. The inclusion of these stakeholders was also highlighted in this issue, emphasizing the need for multiple perspectives and attention to defining and measuring developmental outcomes unique to this population. We hope that this special issue ignites a spark in future research and programming, encouraging the field of youth development to further advance interdisciplinary perspectives that include not only a focus on immigrant, refugee, and border youth, but also include their voices. The current sociopolitical environment demands that we listen to the youth and engage in critical dialogue concerning their experiences in the United States. We have the opportunity to connect with these populations within their communities more authentically and continue to amplify their voices in our programs, policies, and research, especially in our dissemination practices. By centralizing the experience of immigrant, refugee, and border youth we have begun to better understand the structures that shape their lives and foster changes that will better support their development to adulthood. It is the purpose of our field and our responsibility.

\section{References}

Child Migration Data Portal. Retrieved June 5, 2019 from https://migrationdataportal.org/themes/childand-young-migrants

Bejarano C. (2015) Fear, vulnerability, and death for children and youth at the US-México border. In: C. Harker, K. Hörschelmann, T. Skelton (Eds.), Conflict, violence and peace (GCYP, vol 11). Singapore: Springer. Retrieved from https://link.springer.com/referenceworkentry/10.1007\%2F978-981-4585-98-9_10-1

Gabriel, M. G. (2019). Christian faith in the immigration and acculturation experiences of Filipino American youth. Journal of Youth Development, 14(2), 115-129. doi:10.5195/jyd.2019.710

Langley, C. A., Powell, G. M., Liechty, T., Haller, W., \& Anderson, D. (2019). Leisure experiences and social support systems of Latino students with DACA status. Journal of Youth Development, 14(2), 79-98. doi:10.5195/jyd.2019.704

León, M. (2019). Immigrant youth in juvenile facilities: A state-by-state review of recreation programming. Journal of Youth Development, 14(2), 182-203. doi:10.5195/jyd.2019.712

Manzano-Sanchez, H., Matarrita-Cascante, D., \& Outley, C. (2019). Barriers and supports to college aspiration among Latinx high school students. Journal of Youth Development, 14(2), 25-45. doi: $10.5195 / j y d .2019 .685$

Mata-Codesal, D., \& Peperkamp, E., \& Tiesler, N.C. (2015). Migration, migrants and leisure: Meaningful leisure? Leisure Studies, 34(1), 1-4. 
Perspectives: Immigrant, Refugee, and Border Youth

Migration Policy Institute. (n.d.). Children in U.S. immigrant families. Retrieved June 18, 2019 from https://www.migrationpolicy.org/programs/data-hub/charts/children-immigrant-families

Moncloa, F., Erbstein, N., Subramaniam, A., \& Diaz Carrasco, C. (2019). Guiding principles for reaching and engaging latinx youth in youth development programs. Journal of Youth Development, 14(2), 46-63. doi:10.5195/jyd.2019.679

Monte Verde, P., Watkins, M., Enriquez, D., Nater-Vazquez, S., \& Harris, J. C., Jr. (2019). Community youth development service-learning: trauma-informed and culturally responsive. Journal of Youth Development, 14(2), 99-114. doi:10.5195/jyd.2019.714

Radford, J. (2019). Key findings about U.S. immigrants. Retrieved June 18, 2019 from https://www.pewresearch.org/fact-tank/2019/06/17/key-findings-about-u-s-immigrants/

Rodriguez, D. X., Rodriguez, S. C., \& Zehyoue, B. C. V. (2019). A content analysis of the contributions in the narratives of DACA youth. Journal of Youth Development, 14(2), 64-78. doi: $10.5195 / j y d .2019 .682$

Skuza, J.A. (2005). Understanding the experiences of immigrant adolescents: Acculturation is not the same as assimilation. In P. Witt \& L. Caldwell (Eds.), Recreation and youth development (pp. 384-405). State College, PA: Venture Publishing.

Skuza, J.A. (2007). Humanizing the understanding of the acculturation experience with phenomenology. Human Studies, 30 (1), 447-465. Retrieved at http://www.jstor.org/stable/27642813?seq=1\#page_scan_tab_contents

Skuza, J. A., (2019). Teens in the Somali diaspora: An evaluative program study. Journal of Youth Development, 14(2), 153-165. doi:10.5195/jyd.2019.703

Stark, M. D., Quinn, B. P, Hennessey, K. A., Rutledge, A. A., Hunter, A. K., \& Gordillo, P. K. (2019). Examining resiliency in adolescent refugees through the tree of life activity. Journal of Youth Development, 14(2), 130-152. doi:10.5195/jyd.2019.692

Tzenis, J. A. (2019). Understanding youths' educational aspirations in the Somali diaspora. Journal of Youth Development, 14(2), 10-24. doi:10.5195/jyd.2019.717

U.S. House of Representatives Office of the Law Revision Counsel United States Code. (n.d.). 8 USC 1101: Definitions $\S 42$ (refugee). Retrieved June 17, 2019 from http://uscode.house.gov/view.xhtml?req=granuleid\%3AUSC-prelim-title8section 1101 \& num $=0$ \&edition $=$ prelim

Wu, Y-J., Outley, C., \& Matarrita-Cascante, D. (2019). Cultural immersion camps and development of ethnic identity in Asian American youth. Journal of Youth Development, 14(2), 166-181. doi:10.5195/jyd.2019.708

Zong, J., \& Batalova, J. (2017). Frequently requested statistics on immigrants and immigration in the United States. Migration Policy Institute. Retrieved from 
Journal of Youth Development | http://jyd.pitt.edu/ | Vol. 14 Issue 2 DOI 10.5195/jyd.2019.830

Perspectives: Immigrant, Refugee, and Border Youth

https://www.migrationpolicy.org/article/frequently-requested-statistics-immigrants-andimmigration-united-states-6 